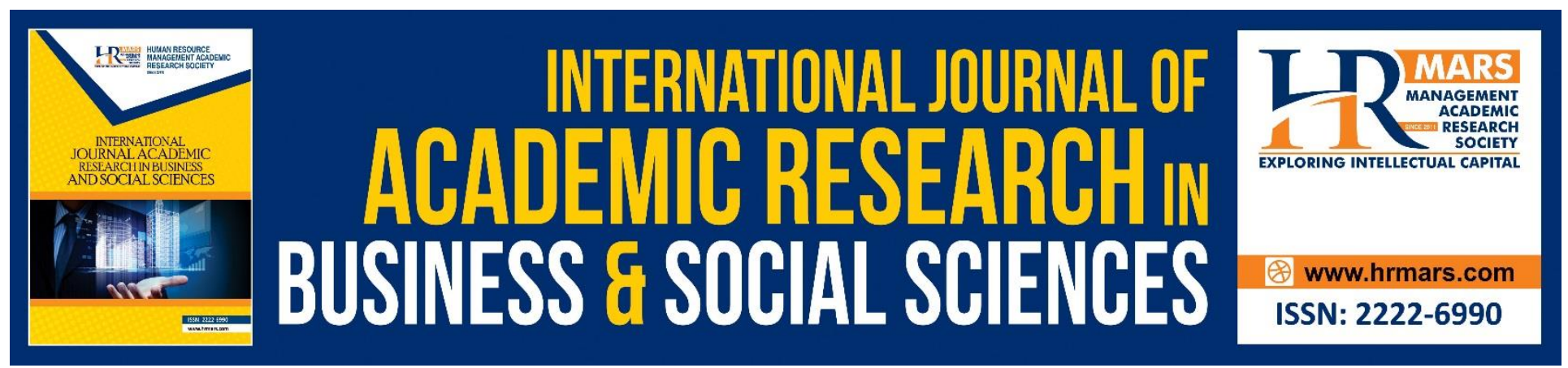

\title{
Development and Effect of Integrated Science Process Skills Module Towards Higher Order Thinking Skills Based on Edutainment
}

\section{Hamidah binti Mat}

To Link this Article: http://dx.doi.org/10.6007/IJARBSS/v9-i2/5638

DOI: $\quad 10.6007 /$ IJARBSS/v9-i2/5638

Received: 28 Jan 2019, Revised: 18 Feb 2019, Accepted: 24 Feb 2019

Published Online: 05 March 2019

In-Text Citation: (Mat, 2019)

To Cite this Article: Mat, H. binti. (2019). Development and Effect of Integrated Science Process Skills Module Towards Higher Order Thinking Skills Based on Edutainment. International Journal of Academic Research in Business and Social Sciences, 9(2), 919-931.

\section{Copyright: (C) 2019 The Author(s)}

Published by Human Resource Management Academic Research Society (www.hrmars.com)

This article is published under the Creative Commons Attribution (CC BY 4.0) license. Anyone may reproduce, distribute, translate and create derivative works of this article (for both commercial and non-commercial purposes), subject to full attribution to the original publication and authors. The full terms of this license may be seen at: http://creativecommons.org/licences/by/4.0/legalcode

Vol. 9, No. 2, 2019, Pg. 919 - 931

Full Terms \& Conditions of access and use can be found at http://hrmars.com/index.php/pages/detail/publication-ethics 


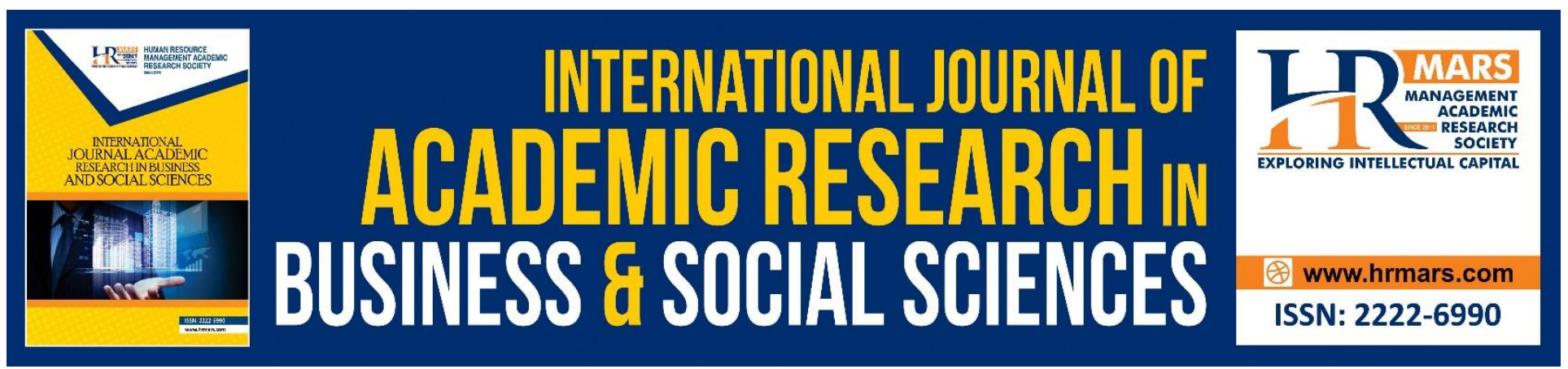

\title{
Development and Effect of Integrated Science Process Skills Module Towards Higher Order Thinking Skills Based on Edutainment
}

\author{
Hamidah binti Mat \\ Universiti Pendidikan Sultan Idris, Tanjong Malim, Perak Darul Ridzuan 35900, Malaysia
}

\begin{abstract}
Module-based teaching is acclaimed to be helpful in guiding teachers to improve teaching through edutainment and for the acquisition of science process skills by the primary school students. Thus, this research involves a development of a module, Integrated Science Process Skills that contains activities as well as questions of higher cognitive levels. The development of this module is based on ADDIE models. In the analysis phase the target group, module levels and cost of production are identified. In the design phase, the objective and background of the module, the concept of the science involved, learning activities, teaching media and evaluation are identified. The module development phase involves the development of the module as it is designed. In the implementation phase, the module is piloted to identify any weakness for improved performance. The assessment phase involves experts in the scientific fields to verify the content and usability of the module. The samples were of 33 treatment group students and 33 control group students. The instruments used are KPS Test, pretest and post test. The results showed that there was an increase in achievement in both treatment and control groups. However, the treatment group showed significantly higher achievement compared to the control group. The findings also shown that there has been an increase in the level of higher order thinking skills in both treatment and control groups with the treatment group showing significantly higher achievement compared to the control group. In conclusion, this study has resulted in a learning module comprising of a complete lesson plan, detailed with higher order thinking skills questions as well as integrated science process skills. Research implications showed that this module can be used by primary school science teachers to improve their students' cognitive level.
\end{abstract}

Keywords: Module, Science Process Skills, ADDIE Models, Edutainment, Cognitive

\section{Introduction}

Science is one of the important subjects in shaping intellectual, competitive and skilled generation of the future. Hence, science education should be seen not only as to pass the exam alone, but also for 
the appreciation and practice of what is learned. Teachers must be smart and creative in choosing and designing appropriate teaching and learning methods as well as to attract students to follow.

Therefore, the chosen method of teaching should take into account the inclination and ability of students based on age and thinking skills. A good teaching method will help students to follow lessons as well as acquire knowledge, skills, as well as to inculcate deep interest in the students. Teaching methods by teachers need to be diversified and adapted according to the topics and themes chosen so as to attract the attention of students and to maximize their impact on teaching and learning (Abdul Jamir, Ab. Halim, \& A'dawiyah, 2012).

\section{Problem Statement}

Ineffective teaching methods for science subjects at primary level can affect students' interest and understanding when they pursue secondary schooling. The phenomenon of memorizing facts, for example, has been detected for a long time among students (Grove \& Lowery B., 2012). This has caused difficulties in many students to understand the basic concepts of science and to manipulate objects for problem solving even though these concepts have been studied.

In addition, a study on the development of higher order thinking skills among SPM students has found that most of the science students (75\%) still work below the higher order thinking skills required in the institutionals of higher learning (Syed A.A. \& Merza, 2000; Hamidah \& Merza , 2001). This situation demonstrates the importance of the need for one such guide as a learning module to focus on the application of higher order thinking skills starting from primary school level. This is due to most primary school students are still weak in mastering these higher order thinking skills. Appropriate teachings and approaches should be used by teachers in applying higher order thinking skills to students.

\section{Methodology}

The design of this study consists of two parts. Part 1 is the development of an integrated sciencebased and integrated process-based science module that incorporates higher order cognitive questions. This module is named Jom Bijak Sains (JBS) module. Part 2 is testing the effectiveness of the module developed in terms of the mastery of integrated science process skills and responding to higher order cognitive questions.

\section{The Development of The Module}

Developing a quality and effective module requires a certain period of time. There are some rules that needed to be followed. The regulations require the researcher to read, study, research, review, understand and explore the various matters relating to the structure and form of the module. Systematic production of modules following every designing steps will produce a good module with continuity in its contents (Saedah et al., 2013). The suitability of the selected design can make the teaching and learning process smoother when using this module.

(a) Module Content 
This module covers all the themes contained in the Standard Education Curriculum (DSKP) Year 5. However, this module focuses more on Integrated Science Process Skills and higher order cognitive questions.

This module incorporates teaching and learning methods based on comfort. This module consists of objectives, materials, procedures and illustrations needed. Each lesson and learning session contained appropriate assessment activities.

b) Development of Module

The development of this module is based on the ADDIE model.

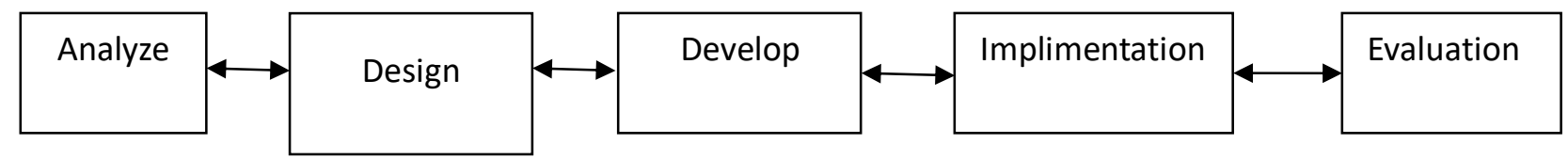

Figure 3.1: ADDIE Model

c) Module Production Cost

Finally is the cost of producing the module. An analysis of the cost of materials and equipment is very important to avoid waste and to avoid the inability to tackle the target group. Therefore, the researcher is trying to apply recycling practices in the selection of project materials as well as reducing the cost of producing the module.

\section{Module Effectiveness}

This study begins with a pretest conducted during the first session of student meeting to identify the strengths, weaknesses, and problems encountered in teaching and learning sessions. Five higher order cognitive questions were given to respondents and should be answered within 30 minutes.

The main focus of this study is to examine the impact on the pupil's ability to master the integrity of the integrated science-based learning process that incorporates elements of higher order thinking skills. All data will be obtained through the pretest and post test methods and integrated science process skills testing.

\section{Sample}

The population studied consists of a total of 210 Year 5 students from a primary school in Negeri Sembilan. To obtain maximum results, a study should include all individuals involved. However, this study did not meet that criteria. Therefore, the researcher has selected 66 samples which can represent the population studied. These students have already sat for the Primary School SelfAssessment (PKSR) during the final semester of the 2015 session. Their test results will be analyzed to select 66 sample surveys based on their achievements. The types of questions assessed in the examination are based on the format of the Primary School Achievement Test (UPSR) issued by the 
INTERNATIONAL JOURNAL OF ACADEMIC RESEARCH IN BUSINESS AND SOCIAL SCIENCES

Vol. 9, No. 2, Feb, 2019, E-ISSN: 2222-6990 C 2019 HRMARS

Ministry of Education. To carry out this study, the researcher divides the selected sample into two groups of 33 students for the treatment group and 33 students for the control group.

\section{Instruments}

Several instruments are used in this study, among them are the Integrated Science Process Skills (KPSB) test developed by Salasiah (2016), the JBS module developed by the researcher, with pre and post trials used to obtain data. The JBS module has been certified by an expert assessment panel comprising of lecturers from Universiti Pendidikan Sultan Idris while the pre and post Test was approved by the supervisor.

The integrated science process skills test developed by Salasiah (2016) consists of 32 different types of items. The answering time is 1 hour. This integrated science process skills test is a type of free content that is not subjected to syllabus issued by the Ministry of Education.

\section{Data Analysis}

Data obtained in this study were analyzed using the paired sample t-test inference statistics. In this study, the null hypothesis has been tested at a significance level of 0.05. According to Chua (2012), paired sample t-test is used when each individual in the sample is measured twice and both normal scattered measurement data are used for comparison. This means that each individual from the experimental group and the control group has two scores for two different levels in the free variables (pre and post).

According to Wiersma (1991), the results of the study will emerge after analysis. Field notes collected will be compiled and synthesized. Summarized data will be manipulated, and reduced to provide the necessary information for the explanation and test hypotheses. Analytical quasiexperimental research is more effortful than analytical experimental studies. Advanced statistical procedures should be used to account for random deficiencies in comparison groups (Kato, 2013). The determination of an appropriate unit of analysis relates directly to the hypothesis of research and questions, samples, and sample assignments for the study conditions (Cohen J., 1988). The researcher needs to be clear in linking the selected analysis unit for major statistical analysis. For the purpose of this study, the researcher had used both descriptive and inferential statistics. Analysis was conducted using the Statistical Program for Social Science (SPSS) version 20.0.

\section{Result and Discussion \\ Features of JBS Module}

Table 4.1 shows the frequency and percentage comparisons of each item, namely:

- Item 1: Cover.

- Item 2: The goal.

- Item 3: Goal.

- Item 4: Investigation steps.

- Item 5: Teacher's assessments.

- Item 6: Learning activities.

- Item 7: Self-reflection.

- Item 8: The content of the module corresponds to the student's academic level. 
INTERNATIONAL JOURNAL OF ACADEMIC RESEARCH IN BUSINESS AND SOCIAL SCIENCES

Vol. 9, No. 2, Feb, 2019, E-ISSN: 2222-6990 C 2019 HRMARS

- Item 9: The contents of the module can be implemented perfectly.

- Item 10: The contents of the module are appropriate to the time allocated.

- Item 11: The contents of the module can give students an understanding of the concept of science.

- Item 12 : The contents of the module can cultivate science process attitude in students.

Table 4.1. Comparison of Frequency, Percentage And Mean For Each Individual Item.

\begin{tabular}{|c|l|c|c|c|}
\hline Items & \multicolumn{1}{|c|}{ Result } & Frequency & Percentage & Min \\
\hline 1 & Agree & 1 & 20 & 4.80 \\
& Strongly agree & 4 & 80 & \\
\hline 2 & Agree & 2 & 20 & 4.80 \\
& Strongly agree & 4 & 80 & 5.00 \\
\hline 3 & Strongly agree & 5 & 100 & 4.40 \\
\hline 4 & Agree & 3 & 60 & 5.00 \\
\hline 5 & Strongly agree & 2 & 40 & 5.00 \\
\hline 6 & Strongly agree & 5 & 100 & 4.80 \\
\hline 7 & Strongly agree & 5 & 100 & 5.00 \\
\hline 8 & Strongly agree & 1 & 20 & 5.00 \\
\hline 9 & Strongly agree & 4 & 80 & 4.40 \\
\hline 10 & Strongly agree & 5 & 100 & \\
\hline 11 & Agree & 5 & 60 & 5.00 \\
\hline 12 & Strongly agree & 3 & 40 & 5.00 \\
\hline
\end{tabular}

The results of the analysis shown in Table 4.1 show that all respondents agree that the design and content of the module conform to the characteristics of a real module. Respondents agreed that all designs including the use of color, instruction, writing and size of the manuscript were in line with the theme and design of a large size module of A4.

Through feedback from the five respondents in Table 4.1, it was found that a module that contains characteristics such as student's academic level, can be implemented perfectly, in accordance with the time allocated, where it can instill the process of scientific inquiry among students, and deliver an understanding of science concept to students more effectively. Improvement of this module is done periodically with regard to each comment either verbally or in writing. Overall, the results of this survey conclude that the JBS module is suitable to be used in teaching and learning of Year 5 science subject.

After comparing the science-wise module and other selected modules, the JBS module showed some strengths, among them the diversity of entertainment activities embodied. Most other modules will focus only on one method of learning unlike the JBS module, which incorporates various methods to master the topic that include visits, role plays, acting, games, experiments and discussions within the group. 
INTERNATIONAL JOURNAL OF ACADEMIC RESEARCH IN BUSINESS AND SOCIAL SCIENCES Vol. 9, No. 2, Feb, 2019, E-ISSN: $2222-6990$ ๑ 2019 HRMARS

According to Zaid and Mohamad (2010), the development of learning modules can help and facilitate the teaching and learning process. A single type of media cannot be used effectively for all teaching purposes. Diversity in learning methods requires the use of diverse media. For this study, JBS modules is used by students based on entertaining lessons such as singing, acting and playing which implement higher order cognitive questions.

It is more likely that students will feel bored when the same method is used for every learning session. In addition, a single type of media or a single kind of method alone may not be suitable for each student learning styles and even less suitable in certain topics. A fun approach to learning is a priority in teaching and learning process of primary school students. This is because playing is in the nature of children and can be a mean and an aid to improve student learning to optimum levels.

\section{Effectiveness of the JBS Module on Students Integrated Science Process Skills}

At the end of the study, students from both groups were given an integrated science process skills test. The test was in the form of objective questions and consists of integrated science process skill questions such as interpreting data, defining operations, controlling variables, hypothesizing and experimenting.

Students' achievement levels from both study groups can be seen through the achievement of the Integrated Science Process Skills test. Based on the t-test (Tables 4.2 and 4.3), both groups showed a moderate level of achievement $(p<.05)$ on the integrated science process skills test. This means that there is no significant difference in student achievement after students are taught using the Jom Bijak Sains module and traditional teaching methods. However, the mean value of the treatment group was higher at 57.36 compared to the control group of 45.55 . This result shows that all students from the treatment group accomplished more than the control group.

Table 4.2 T-Test Statistics Rely on Treatment Groups And Post-Learning Control Groups

\begin{tabular}{|c|c|c|}
\hline Group & Mean & Standard Deviation \\
\hline Treatment & 57.36 & 10.502 \\
\hline Control & 45.55 & 8.924 \\
\hline
\end{tabular}

Table 4.3 T-test Relies on Treatment Groups And Control Group Through Integrated Science Process Skills Testing

\begin{tabular}{|c|c|c|c|c|c|c|}
\hline & F & Sig & t & DF & $\begin{array}{c}\text { Mean } \\
\text { difference }\end{array}$ & $\begin{array}{c}\text { Two-tails } \\
\text { Sig }\end{array}$ \\
\hline $\begin{array}{c}\text { Integrated } \\
\text { Science } \\
\text { Process Skills }\end{array}$ & 3.024 & .087 & 4.926 & 62.374 & 11.818 & .000 \\
\hline
\end{tabular}

As shown in the data analysis, there is no significant difference between the achievement of the treatment group and the control group. However, the mean value of the treatment group was higher at 57.36 compared to the control group at only 45.55. This result shows that the students in the treatment group had accomplished more than the control group. Students of the treatment group 
are able to apply the subject contents as well as increase their understanding of the concepts learned from the information in each activity. This proves that the element of comfort contained in the module generates a happy learning environment in students which in turn encourages students to participate actively in the teaching and learning activities.

The answers given by the treatment group in the integrated science process skills test and during the interview sessions demonstrated a dramatic development of their existing ideas and proved to be a strong conceptual change. Plus, subjects in the treatment group with a larger conceptual changes may not show errors in the integrated science process skills test compared to their peers in the control group (Salawati \& Fatin, 2011).

The improvement of the treatment group students in this study was due to their exposure to the integrated science process skills, while at the same time using the subject's declarative knowledge analytically and creatively. As a result, it enhances students' understanding of topics learned and further supports the findings of Najib Ghafar and Rauf Ibrahim (2011). Students are also actively involved in solving science problems, where their knowledge is always used for new situations. Hence, the more the students are involved in the problem solving process, the further they develop their way of thinking regarding the topic or the subject. In addition, this process is also expected to increase students' understanding of topics or subjects.

The learning process is quite different in the control group. Through observation, the researcher found that the students are taught more by using the "chalk and talk" method. Therefore, they may be described as relatively passive students. They learn more through individual learning than using group discussions. This reduces the opportunity to develop integrated science process skills among the students.

According to Norakma et al. (2015), the use of conventional learning methods is not suitable because it hinders changes in early perceptions of students in regard to where knowledge comes from when they are involved in a discussion or a debate with other students. This situation differs from the approach and method used in the treatment group that require students to understand the subject thoroughly and from there they are able to apply it on the subject matter correctly. It is the basis of problem solving skills that allows students in this group to become more proficient in using and understanding science topics than the students in the control group.

Module-based learning methods are in line with the constructivist approach that students are actively building their own knowledge through group discussions, interactions and information retrievals. On the contrary, the control group had a much lesser chance to explore and build their own knowledge because the knowledge they received were "fed" by their teacher, thus producing different levels of understanding of what is learned (not thoroughly). This distinction is also due to memorization technique method used in the control group and the implementation of integrated science process skills in the module-based learning method. This may explain the significant differences in achievements between the treatment group and the control group. The findings are consistent with other studies conducted by (Folashade \& Akinbobola, 2009; Mokhtar et al.; 2010; Selcuk, 2010; Yaman \& Yalcin, 2005). All of these studies have shown how the use of higher order cognitive questions can improve student achievement, especially in stimulating their integrated science process skills and problem solving (based on Taxonomy Bloom). This finding is also in line with 
INTERNATIONAL JOURNAL OF ACADEMIC RESEARCH IN BUSINESS AND SOCIAL SCIENCES

Vol. 9, No. 2, Feb, 2019, E-ISSN: 2222-6990 C 2019 HRMARS

the Learning Hierarchy identified by Gagne (1965) that classifies problem solving activities as a higher order level of learning.

\section{The Effects of Module Based Learning on Student Thinking Skills}

The effect of using module-based learning can be seen through its higher subtotal in thinking skills analysis using a pretest. Based on the results of the independent sample t-test of the application of higher order thinking skills (Table 4.4 and 4.5), there was no significant difference between both treatment and control groups' pretest scores (mean $=8.45, \mathrm{SD}=3.260)$ ( mean $=7.03, \mathrm{SD}=.568$ ); $\mathrm{t}$ $(64)=-1.907,(p>.05)$. This means that for null hypothesis H02a that there is no significant difference to the higher order thinking skills is accepted.

Based on the results of the t-test of independent samples for the higher order thinking skills (Table 4.4 and 4.5), there was also no significant difference between the treatment group's pretest scores (mean $=5.73, \mathrm{SD}=4.564$ ) and control group's pretest scores (mean = 3.79, SD = 4.357); $t$ (64) $=1.766,(p>.05)$. This means that fo rnull hypothesis H02b that there is no significant difference to the higher order thinking skills analysis is accepted.

In addition, assessment of results from the t-test of independent samples for higher order thinking skills (Table 4.4 and 4.5 ) showed that there is no significant difference between both groups' pretest scores $($ mean $=1.85, \mathrm{SD}=1.064)($ mean $=1.82, \mathrm{SD}=1.158) ; \mathrm{t}(64)=111,(\mathrm{p}>.05)$. This means that for null hypothesis $\mathrm{H02c}$, that there is no significant difference to the higher order thinking skills, is also accepted.

As for the results of the t-test that were independent of the higher order thinking skills (Table 4.4 and 4.5 ) there was no significant difference between the groups' pretest scores, with treatment group's scores of (mean $=2.18, \mathrm{SD}=1.111)$ and control group's scores of (mean $=2.12, \mathrm{SD}=.193)$; $\mathrm{t}$ $(64)=217,(p>.05)$. This means that for null hypothesis H02c it is not significantly different to higher order thinking thinking skills results is accepted.

Table 4.4 Statistical Data on Higher Order Thinking Skills Through Pretest

\begin{tabular}{|l|l|l|l|l|}
\hline $\begin{array}{c}\text { Higher Order } \\
\text { Thinking Skills }\end{array}$ & \multicolumn{1}{|c|}{$\begin{array}{c}\text { Mean } \\
\text { treatment } \\
\text { group }\end{array}$} & \multicolumn{1}{|c|}{ Mean } & \multicolumn{1}{|c|}{$\begin{array}{c}\text { Standard } \\
\text { deviation of } \\
\text { treatment } \\
\text { group }\end{array}$} & $\begin{array}{c}\text { Standard } \\
\text { deviation of } \\
\text { control group }\end{array}$ \\
\hline Application & 8.45 & 7.03 & 3.260 & .568 \\
\hline Analysis & 5.73 & 3.79 & 4.564 & 4.357 \\
\hline Evaluation & 1.85 & 1.82 & 1.064 & 1.158 \\
\hline Synthesis & 2.18 & 2.12 & 1.111 & .193 \\
\hline
\end{tabular}


INTERNATIONAL JOURNAL OF ACADEMIC RESEARCH IN BUSINESS AND SOCIAL SCIENCES Vol. 9, No. 2, Feb, 2019, E-ISSN: $2222-6990$ ๑ 2019 HRMARS

Table 4.5 T-test is Not Relying on Higher Order Thinking Skills Sub Levels Through Pretest

\begin{tabular}{|l|l|l|l|l|l|l|}
\hline $\begin{array}{c}\text { Higher Order } \\
\text { Thinking } \\
\text { Skills }\end{array}$ & \multicolumn{1}{|c|}{ S } & Sig & T-value & Df & $\begin{array}{c}\text { Sig Two } \\
\text { Tails }\end{array}$ & $\begin{array}{c}\text { Mean } \\
\text { difference }\end{array}$ \\
\hline Application & 1.099 & .298 & 1.907 & 62.502 & .061 & 1.424 \\
\hline Analysis & .042 & .839 & 1.766 & 63.863 & .082 & 1.098 \\
\hline Evaluation & .241 & .625 & .111 & 63.549 & .912 & .030 \\
\hline Synthesis & .279 & .599 & .217 & 63.892 & .829 & .061 \\
\hline
\end{tabular}

4.7 T-test is Not Relying on Higher Order Thinking Skills Sub Levels Through Pretest

\begin{tabular}{|l|c|c|c|c|c|c|}
\hline $\begin{array}{c}\text { Higher Order } \\
\text { Thinking Skills }\end{array}$ & F & Sig & T-value & Df & $\begin{array}{c}\text { Sig Two } \\
\text { Tails }\end{array}$ & $\begin{array}{c}\text { Mean } \\
\text { difference }\end{array}$ \\
\hline Application & .857 & .358 & -3.699 & 62.414 & .000 & -2.970 \\
\hline Analysis & 9.607 & .003 & 15.148 & 64 & .000 & 15.515 \\
\hline Evaluation & 4.920 & 0.30 & 5.060 & 64 & .000 & 2.273 \\
\hline Synthesis & 6.498 & .013 & 5.785 & 64 & .000 & 1.788 \\
\hline
\end{tabular}

The effect of using module based learning can be seen through the analysis of higher order thinking skills through pretest and post test. Based on the findings of the independent sample t-test for the 'application' higher order thinking skill (Tables 4.6 and 4.7), there was a significant difference between the treatment group post test scores (mean $=5.76, \mathrm{SD}=2.99$ ) and control group post test scores $($ mean $=8.73, \mathrm{SD}=3.511) ; \mathrm{t}(64)=-3.699,(\mathrm{p}<.05)$. This means that the null hypothesis $\mathrm{H}_{0} 2 \mathrm{a}$ that there is no significant difference to the higher order thinking skill is rejected.

Based on the results of the t-test of independent samples for 'analysis' higher order thinking skill (Tables 4.6 and 4.7), there was a significant difference between the treatment group post test scores (mean $=17.82, S D=5.059)$ and control group post test scores (mean $=2.10, S D=3.005) ; t(64)$ $=15.148,(p<.05)$. This means that the null hypothesis $H_{o} 2 b$ that there is no significant difference to the higher order thinking skills is rejected.

In addition, for the results of the independent samples t-test for the 'evaluation' higher order thinking skill (Table 4.6 and 4.7), there was a significant difference between treatment group's post test scores (mean $=4.58, S D=1.582$ ) and the control group's post test scores (mean $=2.30, S D=$ 2.038); $t(64)=5.060,(p<.05)$. This means that the null hypothesis $H_{o} 2 c$ that there is no significant difference to higher order thinking skills is rejected.

In addition, for the t-test results of the independent samples for the 'synthesis' higher order thinking skill (Table 4.6 and 4.7), there was a significant difference between the groups' post test scores with treatment group scores (mean $=5.67, \mathrm{SD}=.692$ ) and control group scores (mean $=3.88$, $S D=1.6353) ; \mathrm{t}(64)=5.785,(p<.05)$. This means that the null hypothesis $H_{\circ} 2 d$ that there is no significant difference in synthesis of high-level thinking skills is rejected. 
INTERNATIONAL JOURNAL OF ACADEMIC RESEARCH IN BUSINESS AND SOCIAL SCIENCES Vol. 9, No. 2, Feb, 2019, E-ISSN: $2222-6990$ ๑ 2019 HRMARS

Table 4.6 Statistical Data on higher order Thinking Skills Through Post Test

\begin{tabular}{|l|c|c|c|c|}
\hline $\begin{array}{l}\text { Higher -Order } \\
\text { Thinking Skills }\end{array}$ & $\begin{array}{c}\text { Mean } \\
\text { treatment } \\
\text { group }\end{array}$ & $\begin{array}{c}\text { Mean control } \\
\text { group }\end{array}$ & $\begin{array}{c}\text { Standard } \\
\text { deviation of } \\
\text { treatment } \\
\text { group }\end{array}$ & $\begin{array}{c}\text { Standard } \\
\text { deviation of } \\
\text { control group }\end{array}$ \\
\hline Application & 5.76 & 8.73 & 2.990 & 3.511 \\
\hline Analysis & 17.82 & 2.30 & 5.059 & 3.005 \\
\hline Evaluation & 4.58 & 2.30 & 1.582 & 2.038 \\
\hline Synthesis & 5.67 & 3.88 & .692 & 1.638 \\
\hline
\end{tabular}

The results of the analysis have shown that this study has rejected the null hypotheses $\mathrm{H}_{0} 2 \mathrm{a}$, $\mathrm{H}_{0} 2 \mathrm{~b}, \mathrm{H}_{0} 2 \mathrm{c}$, and $\mathrm{H}_{0} 2 \mathrm{~d}$. Based on these four hypotheses, it can be concluded that there is a significant difference between the treatment group and the control group. The enhancement of the students' achievement in the treatment group shows that the module-based learning practiced in teaching and learning is appropriate.

Students from both groups have been given an equivalent amount of pretest and post test questions which are different yet of the same level. The findings showed that both groups have improved in their performance, but what is more interesting is that the achievement is higher in the treatment group. What is obvious here is that modular learning has had a more positive impact on the students achievement than the traditional methods of learning. This is because the activities contained in the module are fun for the students. They can play while learning and actively conduct group activities. This study supports the statements of Bodrova and Leong (2001, 2003), Bruce (2001), Owocki (1991), and Sawyers and Rogers (1998) who previously explained how students' cognitive development can be expanded through fun learning.

At the pretest stage, the achievements of both groups are almost identical. However there was an increase in post test achievement in the treatment group, while the control group did not show an overall improvement. It is possible that the students in the control group are still bound by rote learning which reduces their chances of applying what they had learned.

This study has shown that there is an increased level of thinking skills when students are exposed to a relaxed and comfortable environment when they have to complete a given task. There is a possibility that this skill will remain in the minds of the students once it is created or established. This view is also supported by the decision to implement the module-based learning over a long period of 13 weeks. Within 13 weeks, there was an increase in student achievement compared to the pretest stage. This hands-on experience and fun activities can be obtained through play activities performed inside or out of the classroom. The efforts undertaken by the researcher are also supported by Kamii and Yasuhiko (2006) who state that play activity is better than the use of worksheets. This is because during play the student is given a boost and stimulates the reaction at the same time. 
Implementation of this comfort-learning method shows through posttests that the higher order thinking skills of the treatment group students have a better momentum than the students in the control group. As explained by Nutbrown (1994), play activities given to students actually provide a space for them to build an understanding of nature from the combined result of their own enjoyment, personal experiences and screams. At the end of the learning, students become more skilled in building their own needs and understanding through a supportive and appropriate learning environment.

\section{References}

Abdul Jamir, M. S., Ab. Halim, T., \& A'dawiyah, I. (2012). Pembelajaran Aktif dalam Pengajaran dan Pembelajaran Berkesan Pendidikan Islam. Jurnal IPG Kampus Pendidikan Islam, 1-22.

Bodrova, E., \& Leong, D. J. (2003). Chopsticks and counting chips: Do play and foundational skills need to compete for the teacher's attention in an early childhood classroom? Young Children, $58,10-17$.

Bruce, T. (2001). Learning through play: Babies, toddlers and the foundation years. London: Hodder \& Stoughton

Chua, Y. P. (2012). Kaedah dan statistik penyelidikan buku 2: Asas statistik penyelidikan (Edisi kedua). KualaLumpur: McGraw-Hill (Malaysia) Sdn. Bhd.

Cohen, J. (1988). Statistical power analysis for the behavioral sciences. Statistical Power Analysis for the Behavioral Sciences.

Folashade, A., \& Akinbobola, A. O. (2009). Constructivist Problem-Based Learning Technique and the Academic Achievement of Physics Students with Low Ability Level in Nigerian Secondary Schools. Eurasian J. Phys. Chem. Educ. 1(1), 45-51.

Gagné, R. M. (1965). The Learning of Concepts. The School Review, 75, 187-196.

Grove, N. P., \& Lowery Bretz, S. (2012). A continuum of learning: from rote memorization to meaningful learning in organic chemistry. Chemistry Education Research and Practice, 13(3), 201.

Kamii, C., \& Yasuhiko, K. (2006). Play and mathematics at ages one to ten. In Fromberg, D. P. \& D. Bergen (Eds.),Play from Birth to Twelve, (2nd ed.), pp. 187-198. New York: Taylor and Francis Group.Lee dan Ginsburg (2009)

Kato, K. (2013). Quasi-Bayesian analysis of nonparametric instrumental variables models. The Annals of Statistics, 41(5), 2359-2390.

Mokhtar, M. Z., Tarmizi, M. A. A., Tarmizi, R. A., \& Ayub, A. F. M. (2010). Problem-based learning in calculus course: Perception, engagement and performance. Latest Trends on Engineering Education, 21-25.

Najib Ghafar, M., \& Rauf Ibrahim, A. (2011). Penilaian Hubungan Tahap Penguasaan Konsepsi Sains Dengan Tahap Kemahiran Proses Sains Guru Peringkat Menengah Rendah. Journal of Science and Mathematics Educational, 3, 1-19.

Norakma, M. D., Abdul Razak, A., \& NoriaMunirah, Y. (2015). Pembelajaran Berteraskan Kemahiran Berfikir Aras Tinggi (KBAT) Di Dalam Pengajaran Dan Pembelajaran Mata Pelajaran Sejarah. 7th International Seminar on Regional Education, 1, 352-360.

Nutbrown, C. (1994). Threads of thinking: Young children learning and the role of early 
INTERNATIONAL JOURNAL OF ACADEMIC RESEARCH IN BUSINESS AND SOCIAL SCIENCES

education. London: Paul Chapman Publishing.

Owocki, G. (1991). Literacy through play. Portsmouth, NH:Heinemann.

Saedah Siraj, Norlidah Alias, Dorothy DeWitt, \& Zaharah Hussin. (2013). Design and

developmental research: Emergent trends in educational research. Kuala Lumpur: Pearson Malaysia.

Salawati, S., \& Fatin, A. P. A. (2011). Penguasaan Kemahiran Proses Sains Bersepadu Dalam Ujian Amali Dan Ujian Bertulis Fizik Tingkatan 4. Journal of Edupres, 1(September), 301-305.

Sawyers, J. K. \& Rogers, C. S. (1998). Helping children develop through play: A practical

guide for parents, caregivers and teachers. Washington, DC: National Association for the Education of Young Children.

Selcuk, G. S. (2010). The effects of problem-based learning on pre-service teachers' achievement, approaches and attitudes towards learning physics. International Journal of the Physical Sciences, 5(6), 711-723.

Wiersma, W. (1991). Introduction to research methods in education. British Journal of Educational Technology (Vol. 40).

Yaman, S., \& Yalcın, N. (2005). The effect of problem based instruction in science teaching on creative thinking. Ilkog retim Online, 4(1), 45-52.

Zaid, N. M., \& Mohamad, F. (2010). Pembangunan Modul Multimedia Interaktif Menggunakan Pendekatan Pembelajaran Berasaskan Senario Bagi Tajuk Pembangunan Perisian Multimedia Berasaskan. ... Tajuk Pembangunan Perisian Multimedia .... Retrieved from http://eprints.utm.my/11329/ 